\title{
In Situ Long-Term Reductive Bioimmobilization of Cr(VI) in Groundwater Using Hydrogen Release Compound
}

Boris Faybishenko ${ }^{1}$, Terry C. Hazen ${ }^{1,4}$, Philip E. Long ${ }^{2}$, Eoin L. Brodie ${ }^{1}$, Mark E. Conrad ${ }^{1}$, Susan S. Hubbard ${ }^{1}$, John N. Christensen ${ }^{1}$, Dominique Joyner ${ }^{1}$, Sharon E. Borglin ${ }^{1}$, Romy Chakraborty ${ }^{1}$, Kenneth H. Williams ${ }^{1}$, John E.Peterson ${ }^{1}$, Jinsong Chen ${ }^{1}$, Shaun T. Brown ${ }^{1}$, Tetsu K. Tokunaga ${ }^{1}$, Jiamin Wan ${ }^{1}$, Mary Firestone ${ }^{1}$, Darrell R. Newcomer ${ }^{2}$, Charles T. Resch ${ }^{2}$, Kirk J. Cantrell ${ }^{2}$, Anna Willett $^{3^{*}}$, and Stephen Koenigsberg ${ }^{3 * *}$.

${ }^{1}$ Lawrence Berkeley National Laboratory, Berkeley, CA; ${ }^{2}$ Pacific Northwest National Laboratory, Richland, WA; ${ }^{3}$ Regenesis, Ltd., San Clemente, CA, ${ }^{4}$ Virtual Institute for Microbial Stress and Survival, http://vimss.lbl.gov *Currently with Comprehensive Environmental Utility Services, LLC, New York, NY; **Currently with WSP Environment \& Energy, Irvine, CA.

ABSTRACT. The results of a field experiment designed to test the effectiveness of a novel approach for long-term, in situ bioimmobilization of toxic and soluble $\operatorname{Cr}(\mathrm{VI})$ in groundwater using a hydrogen release compound $\left(\mathrm{HRC}^{\circledR}\right)$ —a slow release glycerol polylactate-are described. The field experiment was conducted at the Hanford Site (Washington), a U.S. Department of Energy nuclear production facility, using a combination of hydrogeological, geophysical, geochemical, and microbiological measurements and analyses of water samples and sediments. The results of this experiment show that a single HRC injection into groundwater stimulates an increase in biomass, a depletion of terminal electron acceptors $\mathrm{O}_{2}, \mathrm{NO}_{3}{ }^{-}$, and $\mathrm{SO}_{4}{ }^{2-}$, and an increase in $\mathrm{Fe}^{2+}$, resulting in a significant decrease in soluble Cr(VI). The Cr(VI) concentration has remained below the background concentration in the downgradient pumping/monitoring well, and below the detection limit in the injection well for more than 3 years after the HRC injection. The degree of sustainability of $\mathrm{Cr}(\mathrm{VI})$ reductive bioimmobilization under different redox conditions at this and other contaminated sites is currently under study.

\section{Introduction}

Chromium (Cr) contamination in soils, surface water, and groundwater is widespread at many sites throughout the world (e.g., 1-3). The most common Cr compounds in groundwater contain hexavalent chromium, $\mathrm{Cr}(\mathrm{VI})$, and trivalent chromium, $\mathrm{Cr}(\mathrm{III})$, which have quite different 
characteristics and properties. $\mathrm{Cr}(\mathrm{VI})$ is mobile and toxic in groundwater, and is present in alkaline and strongly oxidizing aqueous environments as chromate $\left(\mathrm{CrO}_{4}{ }^{2-}, \mathrm{Cr}_{2} \mathrm{O}_{7}{ }^{2-}\right)$ and bichromate $\left(\mathrm{HCrO}_{4}{ }^{-}, \mathrm{H}_{2} \mathrm{CrO}_{4}\right.$ and $\left.\mathrm{HCr}_{2} \mathrm{O}_{7}^{-}\right)$complexes. $\mathrm{Cr}(\mathrm{III})$ complexes are much less toxic (4), and form insoluble and stable precipitates under slightly acidic to neutral conditions in aquifers (5).

Commonly used chemical reductants for converting $\mathrm{Cr}(\mathrm{VI})$ to $\mathrm{Cr}(\mathrm{III})$, with subsequent immobilization of $\mathrm{Cr}(\mathrm{III})$, are: ferrous ion, $\mathrm{Fe}^{2+}(6-10)$; soil organic carbon (11), including humic (12) and fulvic acids (13); and sulfides (14). At Hanford, the Pacific Northwest National Laboratory (PNNL) has recently developed and implemented an In Situ Redox Manipulation (ISRM) technology $(15,16)$, using the injection of sodium dithionite solution into groundwater. Sodium dithionite injection leads to the reduction of $\mathrm{Fe}^{3+}$, releasing $\mathrm{Fe}^{2+}$ needed for $\mathrm{Cr}(\mathrm{VI})$ reduction.

A treatability study of using a hydrogen release compound $\left(\mathrm{HRC}^{\circledR}\right)$, which is a slow release glycerol polylactate (the description of the HRC properties is given in Section "Site Description and Methods”), for Cr(VI) bioreduction in Hanford coarse-grained saturated sediments showed that despite a very low initial total microbial density (from $<10^{4}$ cells $/ \mathrm{mL}$ to $10^{6}$ cells $/ \mathrm{mL}$ ), increased to $>10^{8}$ cells/mL (including sulfate and nitrate reducers) after 3-weeks, and Cr(VI) was practically removed from the pore solution. (In this paper we characterize the microbial biomass using the total number of bacteria, which was determined using direct microscopy after acridine orange staining-AODC.) Although many bacterial strains are known to enhance reduction of $\mathrm{Cr}(\mathrm{VI})$ to Cr(III) both aerobically $(17,18)$ and anaerobically $(19-22)$, only a few studies have examined the in situ potential of $\operatorname{Cr}(\mathrm{VI})$ microbial reduction in subsurface materials (e.g., 23-25). Laboratory studies have also shown that $\mathrm{Cr}(\mathrm{VI})$ reduction in saturated soil aggregates under anaerobic conditions is mainly diffusion-rate-limited and can be strongly transport-controlled and localized $(26,27)$.

The objective of this paper is to describe the results of a field research project of sustained, in situ bioimmobilization of $\mathrm{Cr}(\mathrm{VI})$ in groundwater by transformation of toxic and soluble $\mathrm{Cr}(\mathrm{VI})$ into nontoxic and insoluble Cr(III), using HRC, which mainly contains a slow-release polylactate (28). In this study, the ${ }^{13} \mathrm{C}$-labeled lactate was added to the injected HRC to track post-HRC injection carbon transformation. 


\section{Site Description and Methods}

A plume of $\mathrm{Cr}(\mathrm{VI})$ with concentrations to $>2000 \mathrm{ppb}$ in groundwater was discovered along the Columbia River shoreline to the west of the Hanford 100-D area in the early 1990s. The sources of Cr(VI) contamination are believed to be sodium dichromate used for corrosion control at Hanford's old plutonium reactor systems, decontamination of the shut-down reactor complexes, and leakage from Cr-contaminated unlined drains, cribs, and trenches. Cr(VI) concentrations in groundwater decrease from the source area towards the river shore to 100-200 ppb (>10-20 times the aquatic standard, and >5-10 times the Remedial Action Objective of 20 ppb), and towards the Hanford 100H Area.

The field site for Cr(VI) bioimmobilization is located near the Hanford 100-H Area along the Cr(VI)-contaminated groundwater pathway from the Hanford 100-D Area to the Columbia River (Figure S1, See Supporting Information). To perform field investigations, four $18.3 \mathrm{~m}$ deep, 15 cm diameter boreholes were cored and completed alongside of the existing monitoring Well 69996-43 (drilled and monitored since 1992) in an east-northeast direction (along the regional groundwater flow pathway). The well layout is shown in Figure 1. Borehole drilling and coring techniques are described in Section S1 of Supporting Information. The wells encountered the contaminated, unconfined aquifer in the high-permeability Hanford sediments (gravel and coarse sand) at a depth of approximately $12.2 \mathrm{~m}$. The Hanford sediments are underlain by a clay layer of the Ringold Formation at a depth of $14.3 \mathrm{~m}$, which extends to a depth of $15.25 \mathrm{~m}$, below which is a silty clay to silt layer. Regional groundwater flow direction in the $100-\mathrm{H}$ Area is predominantly to the northeast towards the Columbia River. Results from borehole water-flux measurements (during ambient and pump testing) showed that practically all water entered the boreholes from the sandy gravel of the Hanford formation, with very low flow from the Ringold Formation. The highest

hydraulic conductivity values at the site were detected in the upper part of the Hanford aquifer (29, 30).

Water samples were collected from the different sampling intervals by first applying suction and then injecting argon gas (to prevent cross-contamination) to bring water samples up to the surface. After purging the water samplers, water samples (minimum $100 \mathrm{~mL}$ ) were collected in sterilized vials/flasks, which were first stored on-site at $4^{\circ} \mathrm{C}$ and then sent to the analytical laboratory (by overnight shipment). 
Geophysical measurements included radar time-lapse and seismic cross-borehole surveys, which were performed to: (1) identify lateral heterogeneity of sediments, which may influence the spatial distribution of HRC; and (2) assess the changes associated with the formation and distribution of biogeochemical products. The design, methods, and results of geophysical investigations are described in detail in (29). The relative hydraulic conductivity between the wells was estimated using crosshole geophysical data together with wellbore hydraulic conductivity values determined using an Electromagnetic Borehole Flowmeter (30, 31).

To assess how the biogeochemical processes affect the hydraulic conductivity of saturated sediments, five conservative-tracer $(\mathrm{Br})$ injection tests were performed concurrently with the pumping tests. Two tests were conducted in April-May 2004 and July 2004 to assess pre-HRC injection conditions, one tracer injection was performed immediately after the HRC injection (August 2004), and the other two tests were conducted during June-July 2005 and April-May 2006 to assess post-HRC conditions. Each tracer injection was performed over a period of 2-3 hours into the Hanford sediments of Injection Well (IW) 699-96-45 through two ports at depths of $12.35 \mathrm{~m}$ and $13.1 \mathrm{~m}$. Table S1 summarizes the types of tracers, mass and $\mathrm{Br}$ concentrations, and pumping rates. The information about the data acquisition system is given in Section S1 of Supporting Information.

Microbial and geochemical analyses of water samples were performed using direct cell counts, phospholipid fatty acid (PLFA) analyses (the results of the PLFA analysis will be presented in a separate paper), and PhyloChip high-density DNA microarrays (32, 33). Analyses were carried out to determine dissolved organic carbon (DOC), dissolved inorganic carbon (DIC), $\mathrm{CO}_{2},{ }^{13} \mathrm{C}_{2} \mathrm{O}_{2}$, $\mathrm{CH}_{4}, \mathrm{pH}, \mathrm{Cr}, \mathrm{Fe}, \mathrm{Cl}, \mathrm{Br}$, acetate, $\mathrm{SO}_{4}{ }^{2-}, \mathrm{NO}_{3}{ }^{-}$, and ${ }^{53} \mathrm{Cr} /{ }^{52} \mathrm{Cr}$ ratios of chromium in water samples. Table S2 provides a summary of the methods used for analyses.

On August 3, 2004, $18.2 \mathrm{~kg}$ (40 lbs) of ${ }^{13} \mathrm{C}$-labeled HRC were injected through a specially designed retrievable straddle packer (consisting of two inflatable rubber packers separating the injection interval) into Well 699-96-45 within the Hanford formation from depths of $12.81 \mathrm{~m}$ to $14.03 \mathrm{~m}$. Before the injection, the HRC was pre-heated to about $35^{\circ} \mathrm{C}$ and diluted with 15.1 liters of distilled water. The injection hose was initially filled with 9.5 liters of water (as a primer). 17 liters of water were injected as a chaser after the HRC injection. After the HRC injection, a conservative tracer, $\mathrm{KBr}$, was introduced into the same injection interval of Well 699-96-45 (Tracer Test 4, See Table 
S1), and groundwater was pumped from the downgradient pumping/monitoring well (DPMW) 69996-44 to create a direct water flow path between wells. Pumping continued for 25 days. (Note that $\mathrm{KBr}$ was injected separately from the $\mathrm{HRC}$ injection, because $\mathrm{KBr}$ cannot be mixed in $\mathrm{HRC}$, as HRC does not contain a sufficient amount of water.)

HRC is a viscous, honey-like liquid with a density of $1.3 \mathrm{~g} / \mathrm{cm}^{3}$. The main component of HRC is glycerol polylactate $\left(\mathrm{C}_{39} \mathrm{H}_{56} \mathrm{O}_{27}\right)$, which is an environmentally safe, food grade compound produced by Regenesis, San Clemente, CA. Glycerol polylactate is composed of 12 moles of lactate per mole of glycerol. In addition to glycerol polylactate, HRC contains glycerol and a small percentage of lactic acid and phosphate. Upon hydration, HRC releases lactic acid (34), which provides carbon and energy sources, stimulating both aerobic and anaerobic microbes. Generally, anaerobic microbes ferment the lactic acid into pyruvic acid and then to acetic acid (35), releasing two moles of molecular hydrogen per mole of lactate. Molecular hydrogen is the primary electron donor for microbial reduction of the terminal electron acceptors (TEA)—oxygen, nitrate, iron, and sulfate (36). Polylactate and its breakdown products cause the microbial population to remove the TEAs and to depress the redox potential in the aquifer, creating conditions needed for the transformation of soluble $\mathrm{Cr}(\mathrm{VI})$ species to insoluble $\mathrm{Cr}$ (III) species precipitating on sediment particles. To trace the post-HRC injection carbon production generated by metabolic processes, $10 \mathrm{~g}$ of ${ }^{13} \mathrm{C}$-labeled lactate were mixed with the HRC (with the background $\delta^{13} \mathrm{C}$ value of $-15 \%$ ), resulting in $\sim 40 \%$ of $\delta^{13} \mathrm{C}$.

\section{Results and Discussion}

Background Conditions. The background levels (prior to the HRC injection) of iron, acetate, chloride, bromide, nitrate, sulfate, conductivity, $\mathrm{DO}$, redox, $\mathrm{pH}$ and $\delta^{13} \mathrm{C}$ are given in Table S3. Using the data from the Hanford geochemical database "DaVe2k", we found that $\mathrm{Cr}(\mathrm{VI})$ constitutes about 95\% of the total Cr concentration in water samples. The Cr(VI) concentration under background conditions decreased in Well 696-99-43, from 160-180 mg/L in 1993 to $90 \mathrm{mg} / \mathrm{L}$ in 2002, and then dropped only slightly to $84 \mathrm{mg} / \mathrm{L}$ in 2005 (Figure S2). A slow process of Cr(VI) attenuation under background conditions, with a first-order attenuation constant of $1.7 \cdot 10^{-4}$ day $^{-1}$, is likely caused by the simultaneously occurring processes of groundwater dilution and intrinsic Cr reduction under conditions of regional groundwater flow. Cr(VI) natural attenuation is constrained by the oligotrophic conditions in the aquifer, the presence of nitrate, and a limited amount of ferrous ions in groundwater. 
Sulfate does not limit Cr(VI) reduction, because Cr(VI) reduction occurs at a higher redox potential than sulfate reduction. At the same time, the presence of Fe in groundwater (caused by dissolution of Fe-oxides/hydroxides - e.g., ferrihydrite, hematite, goethite, and magnetite in Hanford sediments) is advantageous for subsequent Cr(VI) reduction (21, 37). The presence of Mn(III, IV) in Hanford sediments (37) could indicate the possibility of Cr(III) reoxidation after HRC depletion. Pre-HRC injection biomass from five water samples collected on July 21 and August 3, 2004 from Wells 69996-44 and 699-96-45 was on average 5 x $10^{5}$ cells/mL.

Post-HRC Injection Measurements. Radar and seismic tomography measurements showed an initial accumulation of HRC near the bottom of the injection interval in IW 699-96-45 (i.e., at the bottom of the Hanford formation). This is most likely due to gravitational settling of the dense HRC. The time-lapse geophysical data suggest that following injection, the HRC byproducts spread upward into the high hydraulic conductivity zone of the Hanford formation, which was the zone most strongly affected by pumping from Well 699-96-44. Specific geophysical results are presented in (29).

The maximum biomass in both the pumping and injection wells was reached at 15-20 days after the injection (Figure 2). The maximum averaged biomass reached $2.5 \cdot 10^{7}$ cells/mL (ranging from $2 \cdot 10^{7}$ to $3 \cdot 10^{7}$ cells $/ \mathrm{mL}$ ) or $\sim 50$ times greater than that before injection in DPMW 699-96-44, and $1.9 \cdot 10^{7}$ cells/mL (varying from $1.3 \cdot 10^{7}$ to $2.3 \cdot 10^{7}$ cells $/ \mathrm{mL}$ ) or $\sim 38$ times greater than background levels in IW 699-96-45. The lower biomass determined in water samples from the injection well possibly results from filtering out bacteria attached to colloids during preparation of water samples for the analyses.

Despite cessation of pumping on August 30, 2008 (27 days after the HRC injection), biomass remained high for the following $\sim 4$ months until December 2004, when it temporarily dropped to $1 \cdot 10^{5}$ cells/mL in the injection well and $4 \cdot 10^{4}$ cells $/ \mathrm{mL}$ in the downgradient pumping/monitoring well. The reason for this drop in biomass is unclear at this time. Following this drop, the biomass in both wells increased again to $5 \cdot 10^{6}$ cells $/ \mathrm{mL}$ in the downgradient monitoring well and $1 \cdot 10^{7}$ in the injection well, and remained at this level until the end of the observation period in June 2007, almost 3 years after the HRC injection.

The results of PhyloChip microarray analysis of water samples show that the HRC injection caused a dramatic initial increase in biodiversity, and, in particular, an enrichment and continuous presence 
of nitrate reducers such as Pseudomonas spp., iron reducers such as Geobacter metallireducens, sulfate reducers such as Desulfovibrio vulgaris, and later, an enrichment of methanogenic archaea. (Detailed results of the PhyloChip analysis will be presented in a separate paper.) As an example, Figure S3 shows the dynamics of Desulfovibrio vulgaris, Geobacter metallireducens, and methanogenic archaea in water samples. The occurrence of these bacteria and archaea suggest a possibility of both direct enzymatically mediated microbial $\mathrm{Cr}(\mathrm{VI})$ reduction and an indirect $\mathrm{Cr}(\mathrm{VI})$ reduction through byproducts of microbial metabolism such as $\mathrm{Fe}^{2+}$ and reactive sulfides (21, 22, 38, 39).

The HRC injection generated reducing conditions, which is evident from the drop in the DO concentration from 8.2 to $0.35 \mathrm{mg} / \mathrm{L}$ and redox potential from 240 to $-130 \mathrm{mV}$ in DPMW 699-9644 (Figure 3). Although DO in IW 699-96-45 increased to $5.5 \mathrm{mg} / \mathrm{L}$ after the end of pumping, it then gradually decreased over the next year. DO in DPMW 699-96-44 was practically stable, ranging from 6 to $7 \mathrm{mg} / \mathrm{L}$, compared with 8 to $9 \mathrm{mg} / \mathrm{L}$ in the upgradient monitoring well (UMW) 699-96-43. At the same time, $\mathrm{pH}$ dropped from 8.9 to 6.5-7.0 and stabilized at this level. Redox potential and DO in the injection and downgradient monitoring wells did not return to the background levels by June 2007. The process of slow recovery of background redox conditions could have been caused by the presence of some HRC breakdown products (like lactic and acetic acid, see Figure S5) between the injection and downgradient monitoring wells. We also hypothesize that the post-HRC injection decaying biomass could itself serve as a carbon and energy source.

An increase in the $\delta^{13} \mathrm{C}$ of DIC from -12\%o (prior-HRC injection) to greater than 50\%o, which is higher than that in the injected HRC (Figure S4), could likely be caused by the creation of $\mathrm{CO}_{2}$ as a byproduct of microbial metabolism (e.g., 40). Note that the release rate of ${ }^{13} \mathrm{C}$-labelled lactate that was added to the HRC could be higher than that of polylactate, which is the main component of HRC. The carbon isotope ratios of the DIC decreased after pumping was stopped, but remained above background for the 3-year period of observations through June 2007, except the depth of 13.1 m (just below the water table) in DPMW 699-96-44.

Different patterns of sulfate and nitrate concentrations were observed in the injection and downgradient monitoring/pumping wells. In the injection well (Figure S6a), sulfates and nitrates were depleted during the $1^{\text {st }}$ year after the HRC injection. During the pumping tests in 2005 and 
2006, their concentrations increased, likely because of regional flow containing sulfates and nitrates. In the downgradient monitoring/pumping well, sulfates and nitrates were depleted during the $1^{\text {st }}$ post-HRC injection pumping, followed by their recovery after the pumping ceased, as a result of mixing with a regional groundwater flow. During the 2005 pumping test, nitrate and sulfate concentrations dropped again, which likely resulted from capturing water with depleted sulfates and nitrates from the area between the injection and the monitoring/pumping wells.

The concentration of aqueous $\mathrm{Fe}^{2+}$ increased in both the injection and downgradient pumping/ monitoring wells, reaching maximum values about 2 months after the HRC injection (averaged values are shown in Figure 4a, and the results of measurements from all water samples are given in Figure S7). In the downgradient monitoring/pumping well, $\mathrm{Fe}^{2+}$ concentration returned to the background, undetectable, level 2.5 years after the HRC injection, and in the injection well—3.5 years after the HRC injection.

Following the HRC injection, the $\mathrm{Cr}(\mathrm{VI})$ concentration dropped in both the injection and monitoring/pumping wells (averaged values are shown in Figure 4b, and the analytical results of all water samples are given in Figure S8). The $\mathrm{Cr}(\mathrm{VI})$ concentration data analysis shows that, following the HRC injection, the $\mathrm{Cr}(\mathrm{VI})$ reduction rate was 0.626 day $^{-1}$ in IW 699-96-45, 0.455 day $^{-1}$ in water samples and 0.276 day $^{-1}$ in the pumped water from DPMW 699-96-44. These rates are greater than the values of $1.2 \cdot 10^{-3}$ to $1.3 \cdot 10^{-2}$ day $^{-1}$ obtained from laboratory studies of soils (for initial $\mathrm{Cr}(\mathrm{VI})$ concentration of $1,000 \mathrm{mg} / \mathrm{L}$ ) amended with lactate (42). The $\mathrm{Cr}(\mathrm{VI})$ reduction rate is generally dependent on the initial $\mathrm{Cr}$ concentration, the type and composition of organic matter, mineralogy of sediments, redox conditions, etc. $(43,44)$.

In IW 699-96-45, Cr(VI) remained below the undetectable level for more than 3 years after HRC injection. In DPMW 699-96-44, Cr(VI) concentration also initially dropped to a undetectable level, and was below the ambient water quality criteria, AWQC, of $0.011 \mathrm{mg} / \mathrm{L}$ for nonpotable water sources, which are protective of aquatic life and may serve as cleanup goals (see Washington Administrative Code (WAC) 173-201A-240). Then, it gradually recovered and has remained below the background concentration for more than 3 years after the HRC injection. The $\mathrm{Cr}(\mathrm{VI})$ and total Cr concentrations in the two new wells drilled in 2006 (See Figure 1) -Well 699-96-41 (between the injection and downgradient monitoring wells) and Well 699-96-42 (located $5 \mathrm{~m}$ off the line of 
existing wells)—is comparable with those in DPMW 699-96-44, confirming the efficacy of $\operatorname{Cr}(\mathrm{VI})$ bioimmobilization.

The shifts in the isotopic composition $\left({ }^{53} \mathrm{Cr} /{ }^{52} \mathrm{Cr}\right.$ ratios) of chromium in water samples are indicative of a process of biogeochemical reduction of $\mathrm{Cr}(\mathrm{VI})$ to $\mathrm{Cr}(\mathrm{III})$, rather than simple attenuation by dilution or dispersion $(45,46)$. Figure S9 shows that the greatest shift of up to 2\%o of $\delta^{53} \mathrm{Cr}$ relative to background was observed in February 2007 in water samples from DPMW 69996-44 at a depth of $14.0 \mathrm{~m}$. A shift of up to $\sim 1 \%$ of $\delta^{53} \mathrm{Cr}$ was also observed in June 2007 in the downgradient monitoring well 699-96-41. Note that no apparent changes in $\delta^{53} \mathrm{Cr}$ were observed in water samples near the water table (13.1 m depth) in DPMW 699-96-44. The gravitational settling of HRC (which was also observed from geophysical observations (29) and measurements of $\delta^{13} \mathrm{C}$ ) at the bottom of the Hanford formation caused more active biogeochemical processes and a significant shift in $\delta^{53} \mathrm{Cr}$ in this zone.

Biogeochemical processes in the Hanford formation after the HRC injection are likely affected both hydraulic and chemical transport processes. Comparison of the Br-tracer breakthrough curves (BTCs), given in Figure S10, shows that before the HRC injection, the water travel time in July 2004 decreased compared to that in April 2004, and further decreased in August 2004, i.e., simultaneously with the initial HRC distribution in the aquifer. We hypothesize that this decrease in the water travel time could have been affected by the increase in the hydraulic conductivity of Hanford sediments, resulting from the washing out of fine (colloidal) particles from the Hanford sediments during pumping. A post-HRC injection (July 2005 and April 2006) increase in the tracer travel time could likely be explained by the decrease in the hydraulic conductivity of the Hanford sediments, resulting from partial blocking of flow pathways within heterogeneous media by biofilms and gases $-\mathrm{CO}_{2}$ (which is formed because lactic acid dissolves calcite present in Hanford sediments, increasing bicarbonate to the point of $\mathrm{CO}_{2}$ gas saturation and bubble formation) and possibly $\mathrm{N}_{2}$.

The process of $\mathrm{Cr}(\mathrm{VI})$ bioimmobilization in groundwater, by means of its transformation into $\mathrm{Cr}(\mathrm{III})$ under anaerobic conditions, can be presented as a two-phase process. The $1^{\text {st }}$ phase involves the creation of reducing conditions, using microbial stimulation, resulting in depleting terminal electron acceptors, such as oxygen, nitrate, sulfate, and iron, with the creation of dissolved, ferrous ion. The $2^{\text {nd }}$ phase involves the biogeochemical processes affected by both metal-reducing and sulfate- 
reducing (sulfide-producing) bacteria, producing two important agents for reducing hexavalent chromium, ferrous ion and hydrogen sulfide. (Although not analyzed, the characteristic odor of hydrogen sulfide was detected in both injection and downgradient monitoring wells.) A chemical reaction of ferrous ion and hydrogen sulfide with hexavalent chromium may lead to the formation of $\mathrm{Cr}_{1-x} \mathrm{Fe}_{x}(\mathrm{OH})_{3}$ precipitates $(6,47-50)$. The processes of $\mathrm{Cr}(\mathrm{VI})$ reduction are also controlled by the solubility and adsorption of $\mathrm{Cr}$ (III) by solid phases, molecular species, or aqueous complexes (51). Enzymatic reduction of chromate may result in the formation of soluble $\mathrm{Cr}(\mathrm{III})$ organic complexes that can be stable for extended periods of time (52).

Regardless of the prevailing mechanism for $\mathrm{Cr}(\mathrm{VI})$ reduction (direct enzymatic chromate reduction and/or abiotic) and the formation of insoluble Cr(III), the Hanford 100-H field test has shown the potential for in situ $\mathrm{Cr}(\mathrm{VI})$ enhanced immobilization using naturally occurring microorganisms enriched by polylactate. Additional field HRC and tracer injection tests and monitoring along with the development of a reactive transport model are planned to assess biogeochemical processes affecting the groundwater flow dynamics, the presence of some HRC or its byproducts between the injection and monitoring wells, the reoxidation potential of $\mathrm{Cr}(\mathrm{III})$ to $\mathrm{Cr}(\mathrm{VI})$ by $\mathrm{Mn}(\mathrm{IV}$ ) oxides (or even by oxygen at neutral or alkaline conditions) $(53,54)$, and the lactate/polylactate release rates. Additional studies are planned to determine chromium isotope ratios to assess the extent of abiotic reduction of chromium in groundwater.

The biogeochemical and hydrogeological characteristics of the Hanford Site-featuring granular and heterogeneous sediments, and a shallow and fluctuating water table — are similar to many other DOE sites. Adding HRC to a contaminated aquifer may offer an effective approach to the control of $\mathrm{Cr}(\mathrm{VI})$-contaminated aquifers at many contaminated sites.

Acknowledgment: This work was supported in part by the Director, Office of Science, Office of Biological and Environmental Sciences, of the U.S. Department of Energy under Contract No. DEAC02-05CH11231 to Lawrence Berkeley National Laboratory. Pacific Northwest National Laboratory is operated by Battelle for the United States Department of Energy under Contract DEAC06-76RL01830. The project was also funded in part by the Environmental Remediation Science Program, Office of Science, and the Office of Environmental Management of DOE. This project was also funded in part by the DOE Genomics: GTL Program. This project is part of the Virtual 
Institute for Microbial Stress and Survival (VIMSS), http://vimss.lbl.gov. The authors appreciate very much constructive comments given by the anonymous reviewers.

Using the trade names or commercial products in this manuscript is exclusively for the purpose of providing specific information related to the experiments and does not imply recommendation or endorsement by authors of this publication.

Supporting Information is available free of charge via the Internet at http://pubs.acs.org.

\section{References}

(1) U.S. Environmental Protection Agency. Cleaning up the Nations Waste Sites: Markets and Technology Trends; EPA 542-R-96-005; EPA: Washington, DC, 1996.

(2) Beukes, J.P.; Pienaar, J.J.; Lachmann, G.; Giesekke, E.W. The reduction of hexavalent chromium by sulphite in wastewater, Water SA 1999, 25, 363-370.

(3) Cook, K.R.; Sims, R.; Harten, A.; Pacetti, J. In situ treatment of soil and groundwater contaminated with chromium. Technical Resource Guide, EPA 625-R-00-005. EPA: Washington, DC, 2000.

(4) Wong, P.T.S.; Trevors, J.T. Chromium toxicity to algae and bacteria. In Chromium in the Natural and Human Environments; J.O. Nriagu and E. Nieboer, Eds.; John Wiley \&Sons: New York, 305-315, 1988.

(5) Palmer, C.D.; Wittbrodt, P.R. Processes affecting the remediation of chromium-contaminated sites, Environmental Health Perspectives 1991, 92, 25-40.

(6) Eary, L. E.; Rai, D. Chromate removal from aqueous wastes by reduction with ferrous ion, Environ. Sci. Technol. 1988, 22, 972-977.

(7) Eary, L. E.; Rai, D. Chromate reduction by subsurface soils under acidic conditions. Soil Sci. Soc. Am. J. 1991, 55, 676-683.

(8) Fendorf, S E. and G.Li , Kinetics of chromate reduction by ferrous iron, Environ. Sci. Technol. 1996, 30 (5), 1614 -1617.

(9) Anderson, L. D.; Kent, D.B.; Davis, J.A. Batch experiments characterizing the reduction of $\mathrm{Cr}(\mathrm{VI})$ using suboxic material from a mildly reducing sand and gravel aquifer, Environ. Sci. Technol. 1994, 28, 178-185.

(10) Buerge, I. J.; Hug, S. J. Influence of mineral surfaces on chromium(VI) reduction by iron(II). Environ. Sci. Technol. 1999, 33(23), 4285-4291. 
(11) Bartlett, R.; Kimble, J.M.J. Behavior of chromium in soils. II. Hexavalent forms, Environ. Qual. 1976, 5, 383-386.

(12) Wittbrodt, P. R.; Palmer, C. D. Reduction of Cr(VI) in the presence of excess soil fulvic acid, Environ. Sci. Technol. 1995, 29, 255-263.

(13) Wittbrodt, P. R.; Palmer, C. D. Effect of temperature, ionic strength, background electrolytes, and $\mathrm{Fe}(\mathrm{III})$ on the reduction of hexavalent chromium by soil humic substances Environ. Sci. Technol. 1996, 30, 2470-2477.

(14) Pettine, M.; Millero, F. J.; Passino, R. Reduction of chromium(VI) with hydrogen sulfide in $\mathrm{NaCl}$ media. Mar. Chem. 1994, 46, 335-344.

(15) Williams, M.D.; Vermeul, V.R.; Szecsody, J.E.; Fruchter, J.S. 100-D Area In Situ Redox Treatability Test for Chromate-Contaminated Groundwater, PNNL-13349, 2000.

(16) Fruchter J.S. In situ treatment of chromium-contaminated groundwater. Environ. Sci. Tech. 2002. 36(23): 464A-472A.

(17) Katz, S., The analytical biochemistry of chromium. Environ. Health Perspect. 1991, 92, 13-16.

(18) Horitsu, H.; Futo, S.; Miyazawa, Y.; Ogai, S.; Kawai, K. Enzymatic reduction of hexavalent chromium by hexavalent chromium tolerant Pseudomonas ambigua G-1. Agric. Biol. Chem. 1987, 51:2417-2420.

(19) Lovley, D. R. Dissimilatory metal reduction. Annu. Rev. Microbiol. 1993, 47, 263-290.

(20) Lovley, D. R.; Phillips, E. J. P. Reduction of chromate by Desulfovibrio vulgaris and its $c_{3}$ cytochrome, Appl. Environ. Microbiol. 1994, 60, 726-728.

(21) Tucker, M. D.; Barton, L. L.; Thomas, B. M. Reduction of Cr, Mo, Se and U by Desulfovibrio desulfuricans immobilized in polyacrylamide gels. J. Ind. Microbiol. Biotechnol. 1998, 20, 13-19.

(22) Wang, P.; Mori, T.; Komori, K.; Sasatsu, M.; Toda, K.; Ohtake, H. Isolation and characterization of an Enterobacter cloacae strain that reduces hexavalent chromium under anaerobic conditions. Appl. Environ. Microbiol. 1989, 55, 1665-1669.

(23) Gvozdyak, P. I.; Mogilevich, N. F.; Ryl’skii, A.F.; Grishchenko, N. I. Reduction of hexavalent chromium by collection strains of bacteria. Microbiology 1987, 55:770-773.

(24) Ginder-Vogel, M.; Borch, T.; Mayes, M.A.; Jardine, P.M.;.Fendorf, S. Chromate reduction and retention processes within arid subsurface environments, Environ. Sci. Technol. 2005. 39(20), $7833-7839$.

(25) Vermeul, V.R.; Szecsody, J.E.; Truex, M.J.; Burns, C.A.; Girvin, D.C.; Phillips, J.L.; Devary, B.J.; Fischer, A.E.; Li, S-M.W. Treatability Study of In Situ Technologies for Remediation of Hexavalent Chromium in Groundwater at the Puchack Well Field Superfund Site, New Jersey, PNNL-16194, 2006. 
(26) Tokunaga, T.; Wan, J.; Lanzirotti, A.; Sutton, S.; Newville, M.; Rao, W. Long-term stability of organic carbon-stimulated chromate reduction in contaminated soils and its relation to manganese redox status, Environ. Sci. Tech. 2007, 41, 4326-4331.

(27) Tokunaga, T.K.; Wan, J.; Hazen, T.C.; Schwartz, E.; Firestone, M.K.; Sutton, S.R.; Newville, M.; Olson, K.R.; Lanzirotti, A.; Rao, W. Distribution of chromium contamination and microbial activity in soil aggregates, J. Environ. Qual. 2003, 32, 541-549.

(28) HRC Material Safety Data Sheet (MSDS). Aavailable at http://www.regenesis.com/library/HRC_Primer_MSDS_81705.pdf

(29) Hubbard, S.; Williams, K.; Faybishenko, B.; Peterson, J.; Chen, J.; Conrad, M.; Long, P.; Hazen, T. Geophysical monitoring of hydrological and biogeochemical transformations associated with contaminant remediation. Environ. Sci. Technol. 2008. 42 (10), 3757 - 3765.

(30) Waldrop, W.R.; Waldrop, J. K. Electromagnetic borehole flowmeter test near the $100 \mathrm{H}$ Area of the DOE Hanford Facility, Quantum Engineering Corporation. 2003.

(31) Molz, F.J.; Boman, G.K.; Young, S.C.; Waldrop, W.R. Borehole flowmeters: field applications and data analysis, J. Hydrology 1994, 163, 347-371.

(32) Brodie, E.L.; DeSantis, T.Z.; Joyner, D.C.; Baek, S.M.; Larsen, J.T.; Andersen, G.L.; Hazen, T.C.; Richardson, P.M.; Herman, D.J.; Tokunaga, T.K.; Wan, J.M.; Firestone, M.K. Application of a high-density oligonucleotide microarray approach to study bacterial population dynamics during uranium reduction and reoxidation. Appl. Environ. Microbiol. 2006, 72, 6288-6298.

(33) DeSantis, T.Z.; Brodie, E.L.; Moberg, J.P.; Zubieta, I.X.; Piceno, Y.M.; Andersen, G.L. Highdensity universal 16S rRNA microarray analysis reveals broader diversity than typical clone library when sampling the environment. Microb. Ecol. 2007, 53, 371-383.

(34) Sharma, P.K; Voscott, H.T.; Swann, B. M. Enhanced CAH dechlorination using slow and fast releasing polylactate esters, In Anaerobic Degradation of Chlorinated Solvents, V.S. Magar, D.E. Fennell, J.J. Morse, B.C. Alleman, and A. Leeson, Eds., The Sixth International In Situ and On-Site Bioremediation Symposium, San Diego, California, June 4-7, 305-312, 2001.

(35) Gibson, S.A.; Fechner, E.J. Stimulation of reductive dechlorination of tetrachloroethene in anaerobic aquifer microcosms by addition of short-chain organic acids or alcohols, Appl. Environ. Microbiol. 1992, 58 (4), 1392-1393.

(36) Hemond, H.F.; Fechner, E.J. Chemical Fate and Transport in the Environment, San Diego, Academic Press. 1994.

(37) Fredrickson, J.K.; Zachara, J.M.; Kennedy, D.W.; Liu, C.; Duff, M.C.; Hunter, D.B.; Dohnalkova, A. Influence of Mn oxides on the reduction of uranium(VI) by the metalreducing bacterium Shewanella putrefaciens, Geochimica et Cosmochimica Acta 2002. 66 (18), 3247-3262.

(38) Fredrickson, J.K.; Gorby, Y.A. Environmental processes mediated by iron-reducing bacteria. Curr. Opin. Biotechnol. 1996, 7:287-294. 
(39) Ackerley, D.F.; Gonzalez, C.F.; Park, C.H.; Blake, R.; Keyhan, A.; Matin, A. Chromatereducing properties of soluble Flavoproteins from Pseudomonas putida and Escherichia coli. Appl. Environ. Microb. 2004, 70, 873-882.

(40) Conrad, M.E.; Templeton, A.S.; Daley, P.F.; Alvarez-Cohen, L. Seasonally-induced fluctuations in microbial production and consumption of methane during bioremediation of aged subsurface refinery contamination. Environ. Sci. Technol. 1999, 33, 4061-4068.

(41) Bolan, N. S.; Adriano, D. C.; Natesan, R.; B.-J. Koo. Effects of organic amendments on the reduction and phytoavailability of chromate in mineral soil. J. Environ. Qual. 2003, 32:120128.

(42) Jardine, P.M., Fendorf, S.E., Mayes, M.A., Larsen, I.L., Brooks, S.C., Bailey, W.B., Fate and transport of hexavalent chromium in undisturbed heterogeneous soil. Environ. Sci. Technol. 1999, 33 (17), 2939-2944.

(43) Hellerich, L.A., Nikolaidis, N.P. Studies of hexavalent chromium attenuation in redox variable soils obtained from a sandy to sub-wetland groundwater environment. Water Research. 2005, 39, 2851-2868.

(44) Tokunaga, T. K.; Wan, J.; Firestone, M.K.; Hazen, T.C.; Schwartz, E.; Sutton, S.R.; Newville, M. Chromium diffusion and reduction in soil aggregates. Environ. Sci. Technol. 2001, 35, 3169-3174.

(45) Ellis A.S.; Johnson, T.M.; Bullen T.D. Chromium isotopes and the fate of hexavalent chromium in the environment. Science. 2002, 295(5562), 2060 - 2062.

(46) Johnson, T.M.; and Bohlen, T.D. Mass-dependent fractionation of selenium and chromium isotopes in low-temperature environments. In Geochemistry of Non-Traditional Stable Isotopes, Johnson, C.M., Beard B.L. and Albarede, F., Eds.; Mineral. Soc. Am.: Washington, DC, 2004.

(47) Patterson, R.R.; Fendorf, S.E.; Fendorf, M.J. Reduction of chromate by amorphous iron sulfide. Environ. Sci. Technol. 1997, 31: 2039-2044.

(48) Kim, C.; Zhou, Q.; Deng, B.; Thornton, E.C.; Xu, H. Chromium(VI) reduction by hydrogen sulfide in aqueous media: stoichiometry and kinetics, Environ. Sci. Technol. 2001. 35(11), $2219-2225$.

(49) Lan, Y; Deng, B.; Kim, C.; Thornton, E.C.; Xu, H. Catalysis of elemental sulfur nanoparticles on chromium (VI) reduction by sulfide under anaerobic conditions. Environ. Sc. Techn. 2005, 39, 2087-2094.

(50) Sass, B. M.; Rai, D. Solubility of amorphous chromium(III)-iron(III) hydroxide solid solutions. Inorg. Chem. 1987, 26, 2228-2232.

(51) Hansel C. M., Wielinga B. W., Fendorf S. Structural and compositional evolution of Cr/Fe solids following indirect chromate reduction by dissimilatory iron-reducing bacteria. Geochim. Cosmochim. Acta. 2003, 67, 401-412. 
(52) James B. R. and Bartlett R. J. Behavior of chromium in soils. V. Fate of organically complexed Cr(III) added to soil. J. Environ. Qual. 1983. 12, 169-172.

(53) Gauglhofer, J.; Bianchi V. Chromium. In Metals and their compounds in the environment, Merian, E., Ed., VCH, Weinheim, 853-878, 1991.

(54) Makino, T.; Kamewada, K; Hatta, T.; Takahashi, Y.; Sakurai, Y. Determination of optimal chromium oxidation conditions and evaluation of soil oxidative activity in soils. Journal of Geochemical Exploration, 1998, 64 (1-3), 435-441. 


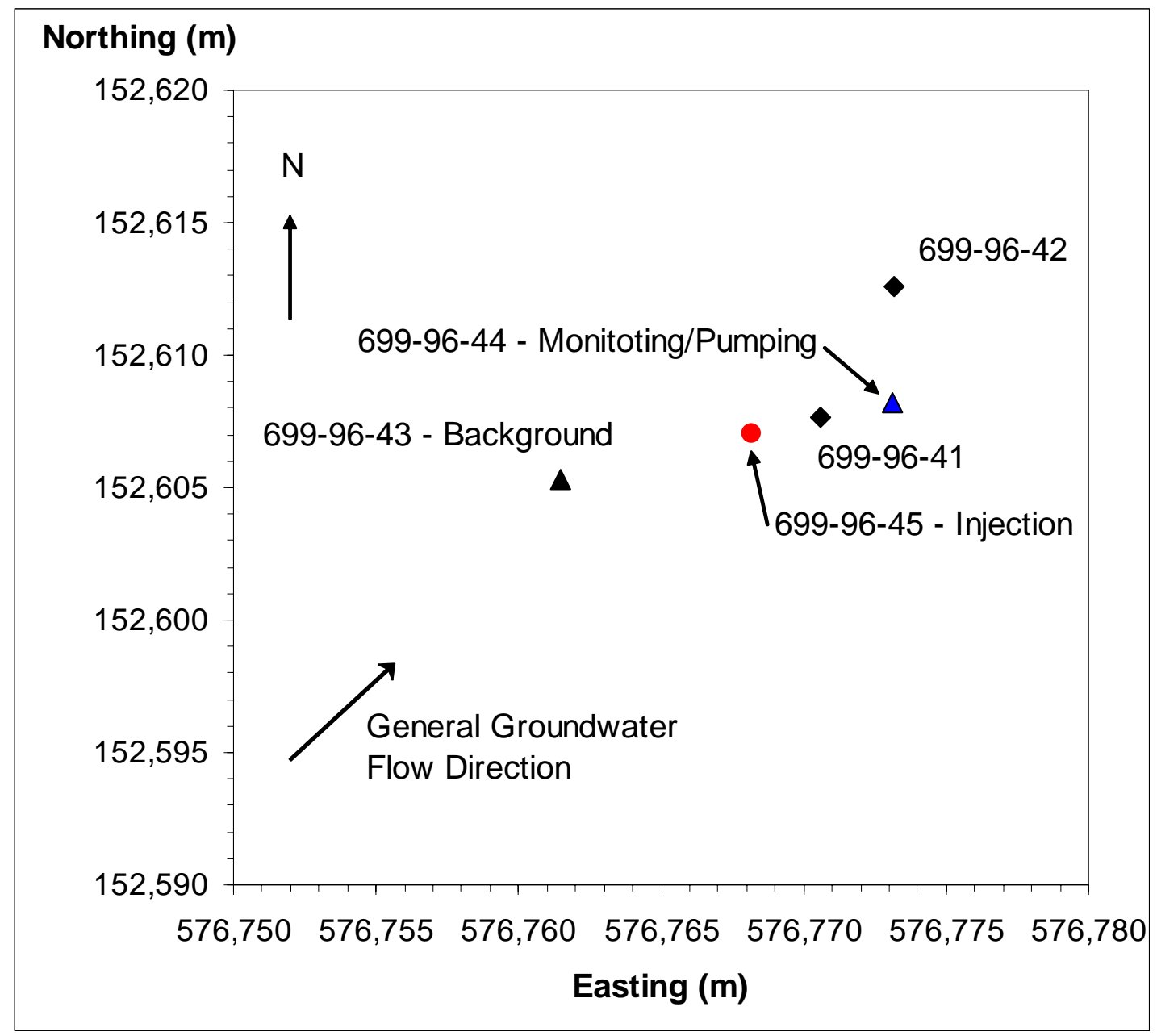

Figure 1. The well layout at the Cr-immobilization research site at Hanford 100-H area. Well 699-9645 was used for the HRC and tracer injections; this well was used for monitoring before and after the HRC and tracer injections. Well 699-96-44, which is located downgradient from IW 699-96-45, was used as a monitoring well and as a pumping well after the HRC injection and during pumping/tracer tests (see Table S1 for the schedule of pumping). Monitoring well 699-96-43 is located upgradient from the injection well and represents background conditions. Downgradient monitoring wells drilled in 2006 are shown with diamond symbols. 

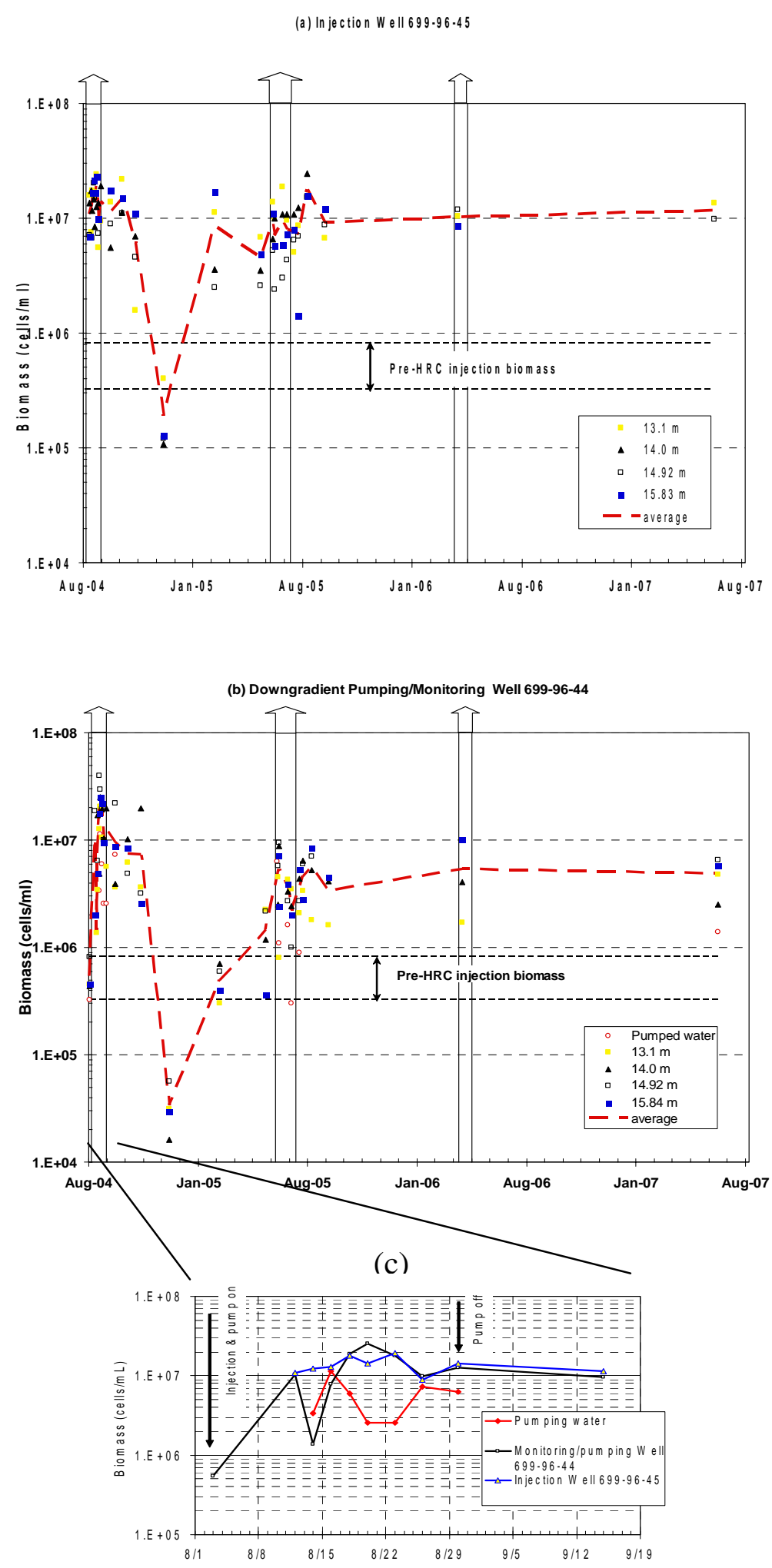

Figure 2. Post-HRC injection changes in biomass in (a) the injection well, (b) downgradient pumping/ monitoring well, and (c) averaged data for July-September 2004. Results are from the acridine orange direct count (AODC) of microbial cells. Vertical arrows indicate the duration of pumping tests—see Table S1. 

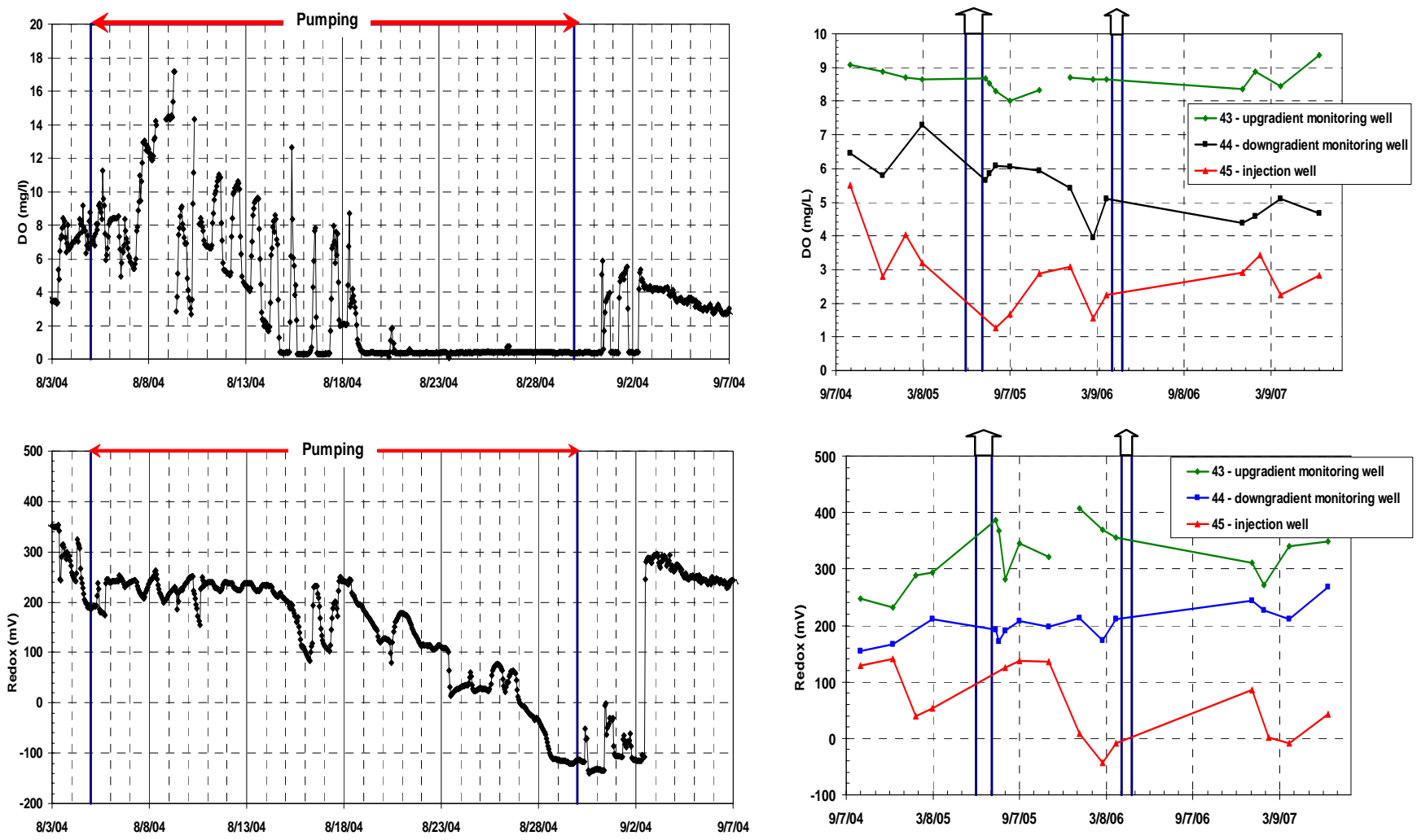

(c)

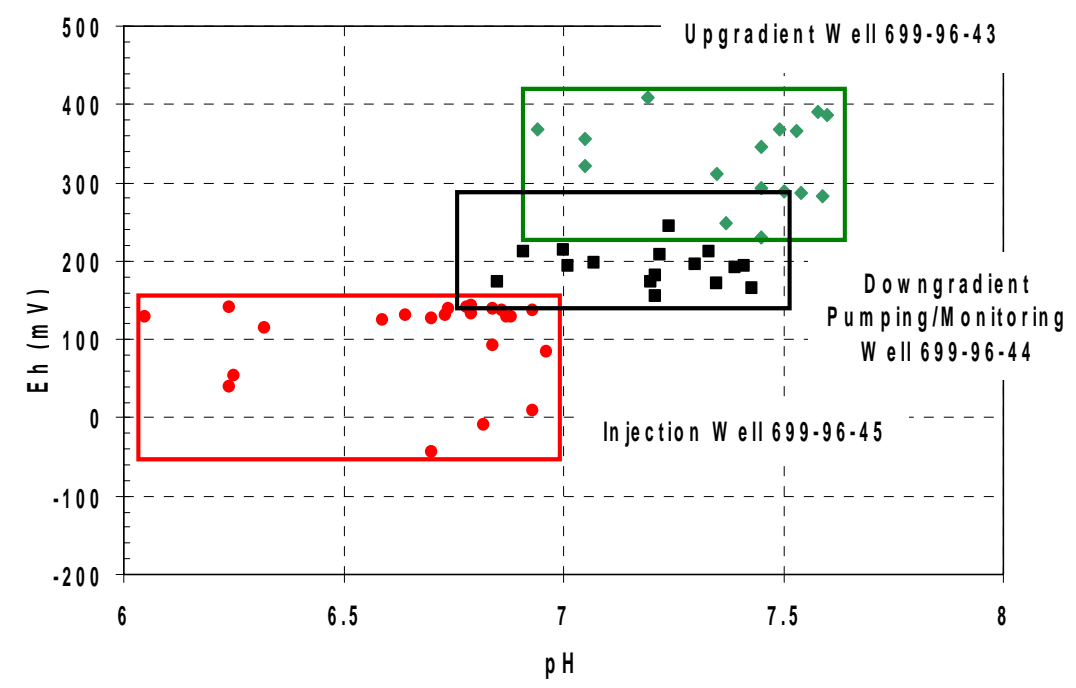

Figure 3. (a) Detailed time variations of DO and redox potential (Eh) during the $1^{\text {st }}$ month after the HRC injection in DPMW 699-96-44, (b) Long-term variations of DO and redox potential in the injection, upgradient monitoring, and downgradient pumping/monitoring wells, and (c) Relation between Eh and $\mathrm{pH}$ from long-term measurements shown in figure (b). Vertical arrows on figure (b) indicate the duration of pumping tests-see Table S1. 


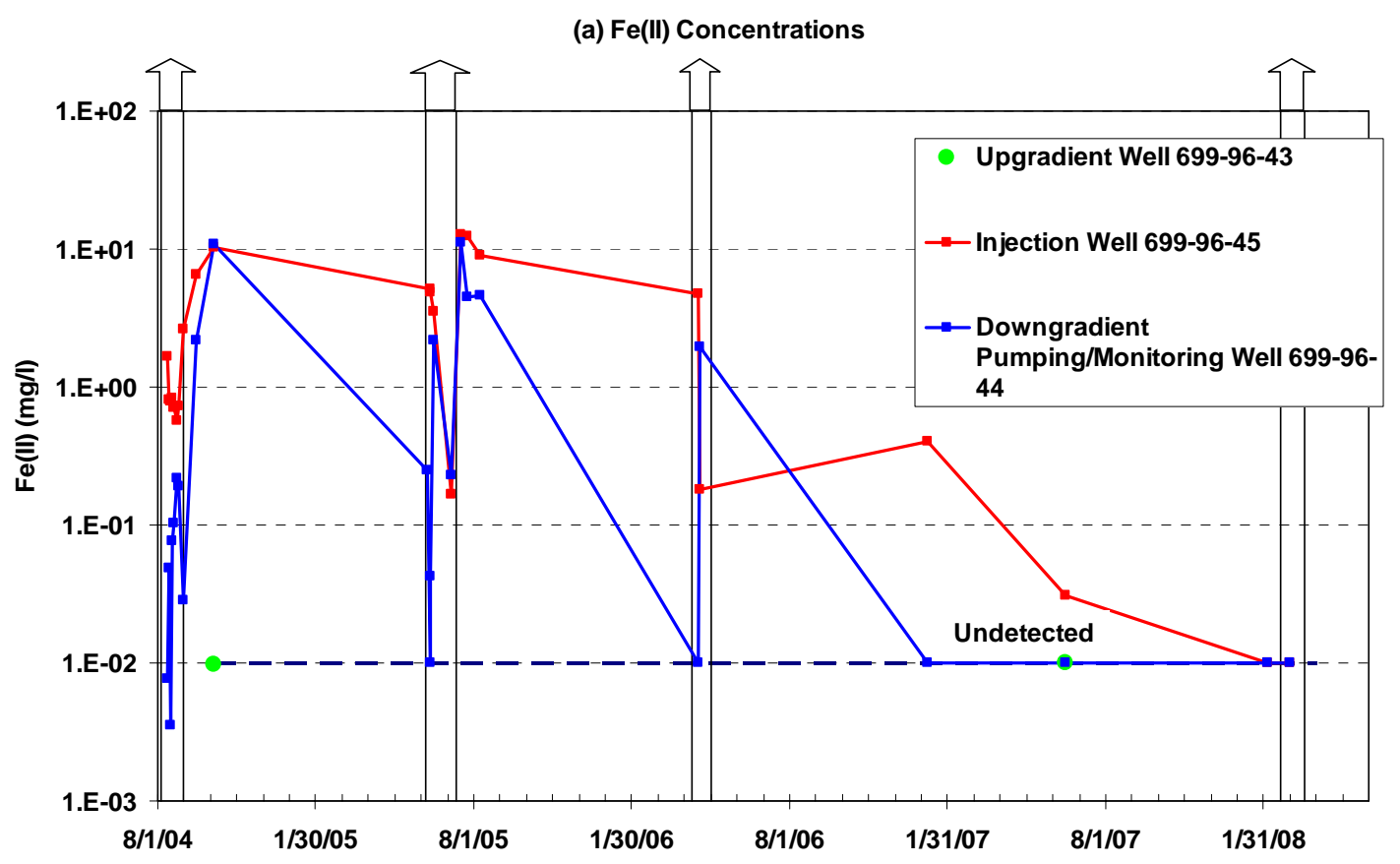

(b) $\mathrm{Cr}(\mathrm{VI})$ Concentrations

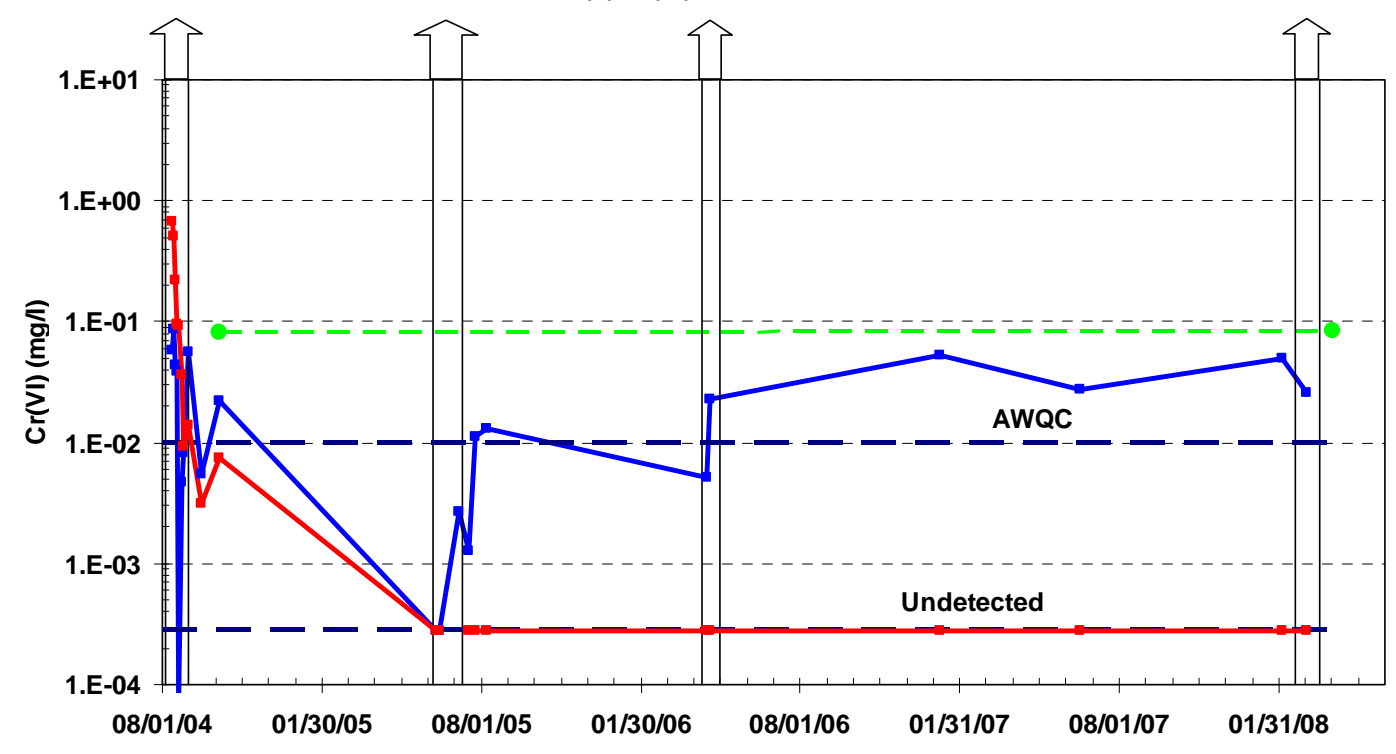

Figure 4. Changes in the averaged Fe(II) (a) and Cr(VI) (b) concentrations in water samples in IW 69996-45 and DPMW 699-96-44. Vertical arrows indicate the duration of pumping tests - see Table S1. Detailed data are shown in Figures S7 and S8.

\section{The Brief}

A single HRC injection into groundwater stimulates an increase in biomass and depletion of terminal electron acceptors, resulting in long-term $\mathrm{Cr}(\mathrm{VI})$ bioimmobilization. 